\title{
Monitoring vertebrate abundance in Austria: developments over 30 years
}

\section{Die Entwicklung von Wirbeltierpopulationen in Österreich in den letzten 30 Jahren}

\author{
Katharina Semmelmayer, Klaus Hackländer*
}

\begin{abstract}
Institute for Wildlife Biology and Game Management, Department of Integrative Biology and Biodiversity Research, University of Natural Resources and Life Sciences Vienna (BOKU), Gregor-Mendel-Straße 33, 1180 Vienna, Austria
\end{abstract}

* Corresponding author: klaus.hacklaender@boku.ac.at

Received: 30 July 2019, received in revised form: 10 February 2020, accepted: 12 January 2020

\begin{abstract}
Summary
Loss of biodiversity is one of the major challenges of the anthropocene. Various indices are used to quantify biodiversity. For vertebrates, the World Wide Fund for Nature (WWF) uses the Living Planet Index (LPI). It is calculated globally as well as separately for the species occurring in terrestrial, freshwater, and marine biomes. Action to prevent biodiversity loss can be taken by countries or provinces, so it is important to understand the changes in biodiversity at local scales. We present LPIs for vertebrates in Austria, both unweighted and weighted, according to species richness. Vertebrate populations seem to have declined strongly in Austria, and their abundance was stabilized at about 60\% of the initial population size in the base year 1990-the LPI declined from 1 in 1990 to $\sim 0.6$ (unweighted) or $\sim 0.7$ (weighted) in 2015 . This is almost double the global decline for the same period. LPIs were calculated separately for the terrestrial biome $(-0.6)$, the freshwater biome $(\sim 0.9)$, birds $(\sim 0.7)$, and native species $(-0.6)$. These indices give evidence that conservation measure to halt biodiversity loss in Austria is necessary and show where more data are needed. In Austria, more research is needed especially on populations of reptile species.
\end{abstract}

Keywords: autochthonous, Living Planet Index, biodiversity loss, biodiversity goals, vertebrate diversity

\section{Zusammenfassung}

Der Verlust an Biodiversität stellt eine der größten Herausforderungen des Anthropozäns dar. Um Biodiversität zu quantifizieren, werden verschiedene Indizes herangezogen. Für Wirbeltiere hat der World Wide Fund for Nature (WWF) den Living Planet Index (LPI) entwickelt. Er gibt die globale Entwicklung der Populationsgröße verschiedener Arten wieder und kann getrennt für die Biome Land, Süßwasser und Meer berechnet werden. Maßnahmen zur Vermeidung von weiterem Verlust an Biodiversität müssen auf Landesebene gesetzt werden. Daher ist es wichtig, über den lokalen Zustand der Biodiversität informiert zu sein. In der vorliegenden Studie wurde daher ein LPI für Wirbeltiere in Österreich entwickelt. Dieser enthält je nach Artendiversität sowohl ungewichtete als auch gewichtete Werte. Die Wirbeltierpopulationen gingen in Österreich stark zurück und haben sich, bezogen auf den Ausgangswert aus dem Jahr 1990, auf einem Niveau von 60 \% eingependelt - der LPI Österreich ging von 1 in 1990 auf $\sim$ 0,6 (ungewichtet) bzw. $\sim 0.7$ (gewichtet) im Jahr 2015 zurück. Damit ist der Rückgang beinahe doppelt so hoch wie der globale Rückgang im selben Zeitraum. LPI-Werte wurden separat für das Biom Land ( $\sim 0.6)$, für Süßwasserlebensräume ( $\sim 0.9)$, aber auch für Vögel $(\sim 0.7)$ und autochthone Arten $(\sim 0.6)$ berechnet. Diese Ergebnisse der Studie bieten die Grundlage für Maßnahmen zum Schutz der Biodiversität und zeigen auch, welche Datenlücken vorhanden sind. So fehlen vor allen Dingen Informationen zu Reptilien.

Schlagworte: autochthon, Living Planet Index, Biodiversitätsverlust, Biodiversitätsstrategie, Wirbeltierdiversität 


\section{Introduction}

Humans have increasing impacts on fauna and flora (Overmars et al., 2014) and are responsible for causing the highest biological extinction rate in the history of the Earth (Balmford et al., 2003). In this context, the aim of the Convention on Biological Diversity (CBD) of 1993, signed by 168 countries including Austria, and ratified since by 196 countries and unions (https://www.cbd.int/ convention/, 08.02.2018), is to protect biological diversity (Secretariat of the Convention on Biological Diversity, 2005). One major goal of the convention was to reduce the loss of biodiversity significantly by 2010 (Secretariat of the Convention on Biological Diversity, 2005). The goal of the European Union was even more ambitious: to stop the loss of biodiversity by 2010 (EU European Council, 2001). Neither goal was reached (Butchart et al., 2010), so the deadlines were extended to 2020 (Conference of the Parties, 2010).

To assess whether or not the goals of the CBD are being reached, indices have been defined to measure biodiversity and quantify changes in space and over time (Ten Brink, 2005). Quantifying global changes in biodiversity enables us to understand more clearly threats to species and ecosystems (McRae et al., 2017). Indices are suitable for this because they enable us to gain information; they are also a means of communication between scientists and politicians (Ten Brink, 2005).
One index of biodiversity, the Living Planet Index (LPI), is designed to compare the diversity of vertebrate species on a global scale or within smaller regions between different years, in relation to a base year. The basic building blocks of the index are population time series of vertebrate species, which require measurement of the population size of each vertebrate species within a certain area for as many years as possible (Legg and Nagy, 2006).

The LPI was first published in 1998 in the Living Planet Report of the World Wildlife Fund for Nature (WWF; Loh et al., 2005) and has been published periodically ever since (http://www. livingplanetindex.org/home/index, 08.02.2018). A database of vertebrate population time series was set up at a global scale and has been developed further as the basis for the index. The calculation procedure has been revised several times to meet modern standards and to incorporate new analysis methods for big data sets (Loh et al., 2005; Collen et al., 2008; McRae et al., 2017). However, the basic structure of the index has not changed (Loh et al., 2005). As the calculation is performed in a stepwise manner, it is possible to disaggregate the global LPI into indices for the three biomes, for a climate region, or for a species (Figure 1). Although the database used for the calculation is one of the largest on vertebrate species worldwide (WWF, 2016), it is not possible to generate an index for each country because of insufficient data (McRae et al., 2008).

We aimed to generate enough data to calculate an LPI for Austria (a mountainous land-locked country in Central

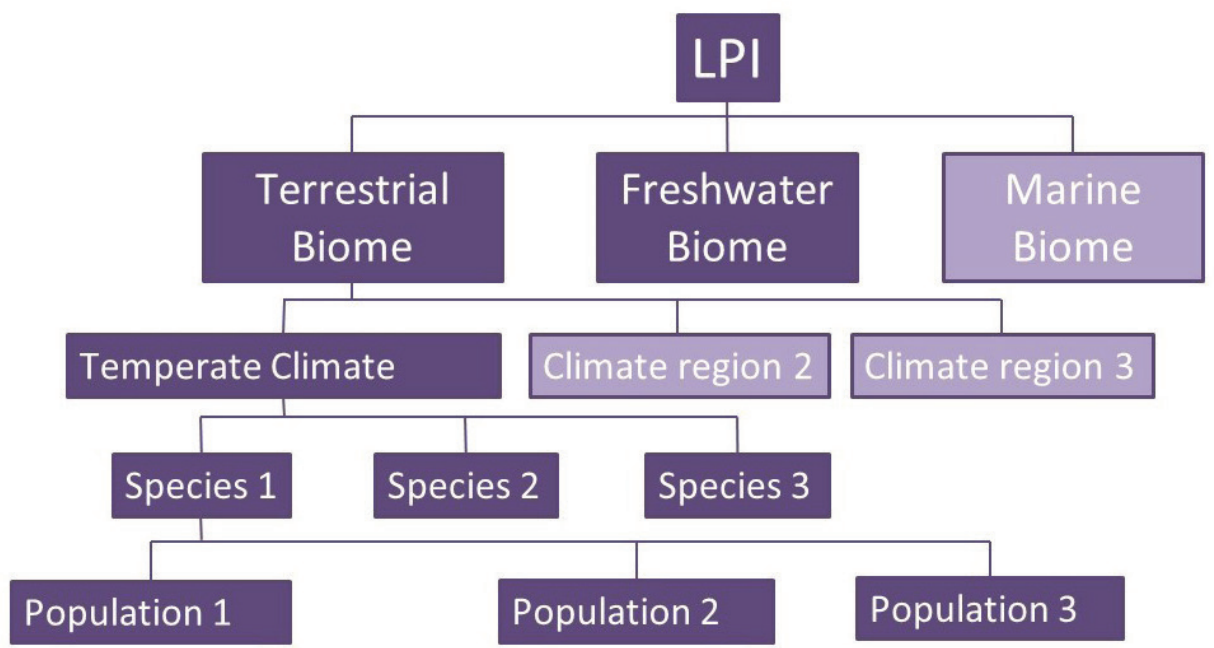

Figure 1. The structure of the Global Living Planet Index (LPI). The parts that are relevant for Austria, a land-locked country, are dark. Modified from Loh et al. (2005).

Abbildung 1. Aufbau des Globalen Living Planet Index (LPI) mit Markierung der relevanten Schritte für den österreichischen LPI (dunkel). Quelle: Loh et al., 2005, eigene Bearbeitung. 
Europe, with an area of ca. $84,000 \mathrm{~km}^{2}$ ) and also for each of its nine provinces. This is a new approach for the country, as the conservation status of Austrian fauna has previously been and still is described by using Red Lists (Gepp, 1984). There are many projects and monitoring activities on species in Austria, especially to fulfill the documentation requirements of the European Council Directive 2009/147/EC on the conservation of wild birds (Birds Directive) and the European Council Directive 92/43/ EEC on the Conservation of natural habitats and of wild fauna and flora (Habitats Directive) and also within other projects that are financed or co-financed by the European Union, such as Life- and Life+-projects. Furthermore, monitoring has been performed in protected areas and on species causing conflicts, such as the Eurasian beaver (Castor fiber; e.g., Habenicht, 2014) and the Eurasian otter (Lutra lutra; e.g., Sittentaler et al., 2016). The data from all these projects have never been combined to gain insight into the conservation status of vertebrate species in Austria. Only certain classes or groups of species have been analyzed by certain organizations, for example, by BirdLife Austria, an organization concentrating on birds and their protection, and by "Koordinationsstelle für Fledermausschutz", a non-governmental organization concentrating on bats. The aim of this study was to aggregate data from different projects and organizations to calculate an LPI for the stages of disaggregation relevant for Austria (Figure 1, dark boxes). Reaching this goal would allow to make use of the index in several ways:

1. To gain an insight into the conservation status of Austrian vertebrate populations.

2. To show where ongoing monitoring and new monitoring projects are needed.

3. To form a baseline for fulfilling reporting duties to the European Union or within the frame of the CBD.

\section{Material and Methods}

\subsection{Data requirements and collection}

To calculate an LPI, only population time series that are available for several (at least two) years for a vertebrate species are included only if the data were collected using the same method and intensity of collection in the same study area in each of the study years (Collen et al., 2008). Time series may be of total population counts or of proxies of population size such as density measures (McRae et al.,
2008). Fishing catch data, hunting bags, and other nonscientific data are not used (Loh et al., 2005). Data from scientific research as well as from the gray literature are included (Collen et al., 2008).

Data were obtained from the Environment Agency Austria, the Austrian Federal Ministry for Sustainability and Tourism, Austrian State Forest, non-governmental organizations, management units of protected areas, scientists, and associations working in the field of nature protection. In addition, the database zobodat.at, which focuses on scientific literature on Austrian fauna and flora, was searched. To enable us to check the reliability of the data, sources and information on the study design and area (Collen et al., 2008) were gathered in a database (Microsoft Access 2010). Furthermore, the information on the habitat used by each species was gathered to enable the generation of disaggregated indices (Collen et al., 2008).

\subsection{Statistical analysis}

Data availability for each year and province were analyzed descriptively (Microsoft Excel 2010). For further statistical analysis, the package rlpi (Freeman et al., NA) in the statistical program R version 3.3.1 (R Core Team, 2016) was used. For the global LPI, time series including 6 or more years of data are processed using generalized additive models (GAMs; Collen et al., 2008), whereas those including fewer years are processed using a chain method (Loh et al., 2005). The chain method is used to compare numbers of species over a time period with missing values for some years (Ter Braak et al., 1994). In order to calculate an index by this method, pairs of successive years are first used to estimate the logarithm of the ratio from one year to the preceding (Loh et al., 2005). If there are several time series for the same species in one year, the mean is calculated first. Those values are then chained to the base year, resulting in the yearly index values (Ter Braak et al., 1994). GAMs were used for time series with a number of observation years of $>5$. They are more flexible than the chain method, as the mean abundance may follow any smooth curve, even a non-linear one. This is the advantage over the chain method (Collen et al., 2008). However, longer time series are needed to generate reliable results. In the calculation method, the geometrical mean is used to calculate indices for the time series (Vačkár et al., 2012).

To generate reliable indices, only time series with at least three observation years should be used (Dobson, 2005). As most time series for Austrian vertebrate populations had only two or three observation years and as GAMs are 
preferred over the chain method (Fewster et al., 2000), only time series with at least 5 observation years were used for the calculation of the Austrian LPI.

To calculate the GAM, data for amphibians and reptiles were combined into a "herpetological class" because of insufficient data. Furthermore, according to data availability, the base was set to 1990 instead of the global base 1970 (Loh et al., 2005). Apart from these changes, the calculation was carried out in an automated way (McRae et al., 2017) by the R-package rlpi, following the stepwise procedure described by Collen et al. (2008):

- Fit a GAM in which $\log _{10}\left(\mathrm{~N}_{\mathrm{t}}\right)$ is the dependent variable, Year $(t)$ is the independent variable, and $N_{t}$ is the population value $\mathrm{N}$ of a time series in year $\mathrm{t}$.

- Set smoothing parameters.

- Calculate population estimates for the whole time span, including log-linear interpolation for years without observations.

- Calculate confidence intervals using the 100-repetition boot-strapping method (Collen et al., 2008).

Bootstrapping is a widely used method to calculate confidence intervals by drawing random samples with replacement from the collected data (Collen at al., 2008). It is also important to mention that index values for missing years were exclusively generated by interpolation (Collen et al., 2008), thus no extrapolation to years before the first or past the last year of data collection was performed.

Data were processed according to MacRae et al. (2017), using the unweighted approach and also with weighting. Therefore, data were converted into .csv-tables (Table 1) and further processed using infiles generated in R. Infiles provide the information on the location of the data used for index calculation and on the weighting of time series within the index (MacRae et al., 2017). For detailed information on the calculation, see https://github.com/Zoological-Society-of-London/rlpi (03.07.2018).

Weighting according to species richness in each class was carried out (Table 2), but weighting was not carried out for each province (McRae et al., 2017).

\section{Results}

\subsection{Data availability}

A total of 2,145 time series for Austrian vertebrate populations were collected. After rejection of short time series (mostly 2 or 3 years) and series with long gaps between years of data collection, 873 time series, representing 268 vertebrate species, could be used in the calculation of the LPI. Most time series were obtained from the provinces Upper Austria and Carinthia; there were few time series from the Tyrol and Vorarlberg (Figure 2).

Data availability increased overall from the mid-1990s to 2010 , with a decrease only in 2003 . There were a minimum of 125 data points in 1996 and a maximum of 636 in 2010. After 2010, the number of data points decreased again (Figure 3).

\subsection{The Living Planet Indices}

The LPI was calculated for Austria and separately for the terrestrial biome, the freshwater biome, species that were classed as native (autochthonous) to Austria by the International Union for Conservation of Nature (http://www. iucnredlist.org/, 28.11.2017), and birds. Owing to insufficient data, separate LPIs could not be calculated for mammals, fish, the herpetological class, or each of the Austrian provinces.

The Austrian LPI was calculated unweighted and weighted according to species richness in each class (Table 2). The unweighted index shows a decrease in 1991, followed by a small increase in 1992 and decreases until 1997. Since then, it has been fluctuating between 0.4 and 0.7 , being closer to 0.7 in more recent years. The weighted LPI has a more pronounced increase in the first half of the 1990s than the unweighted one and shows stronger fluctuations in the following years until 2015, with peaks reaching almost 0.8 (Figure 4).

The LPI for the terrestrial biome contained 837 time series, representing 243 species, whereas only 60 time series (representing 40 species) could be used for the calculation of the freshwater LPI. Owing to data availability, the terrestrial LPI was very similar to the Austrian index. For the freshwater index, no reliable results could be obtained because of the little data available resulting in extremely large confidence intervals (Figure 5).

The LPI for birds (Figure 6, left), based on 547 time series representing 205 species, showed a decrease below 0.6 in the mid-1990s and between 2000 and 2005, but in between and since then, it has been increasing and increased to -0.7 by 2015 .

The 812 time series representing 241 species were used to create the LPI for species native to Austria, which was similar to the unweighted LPI for Austria: it showed a decrease 


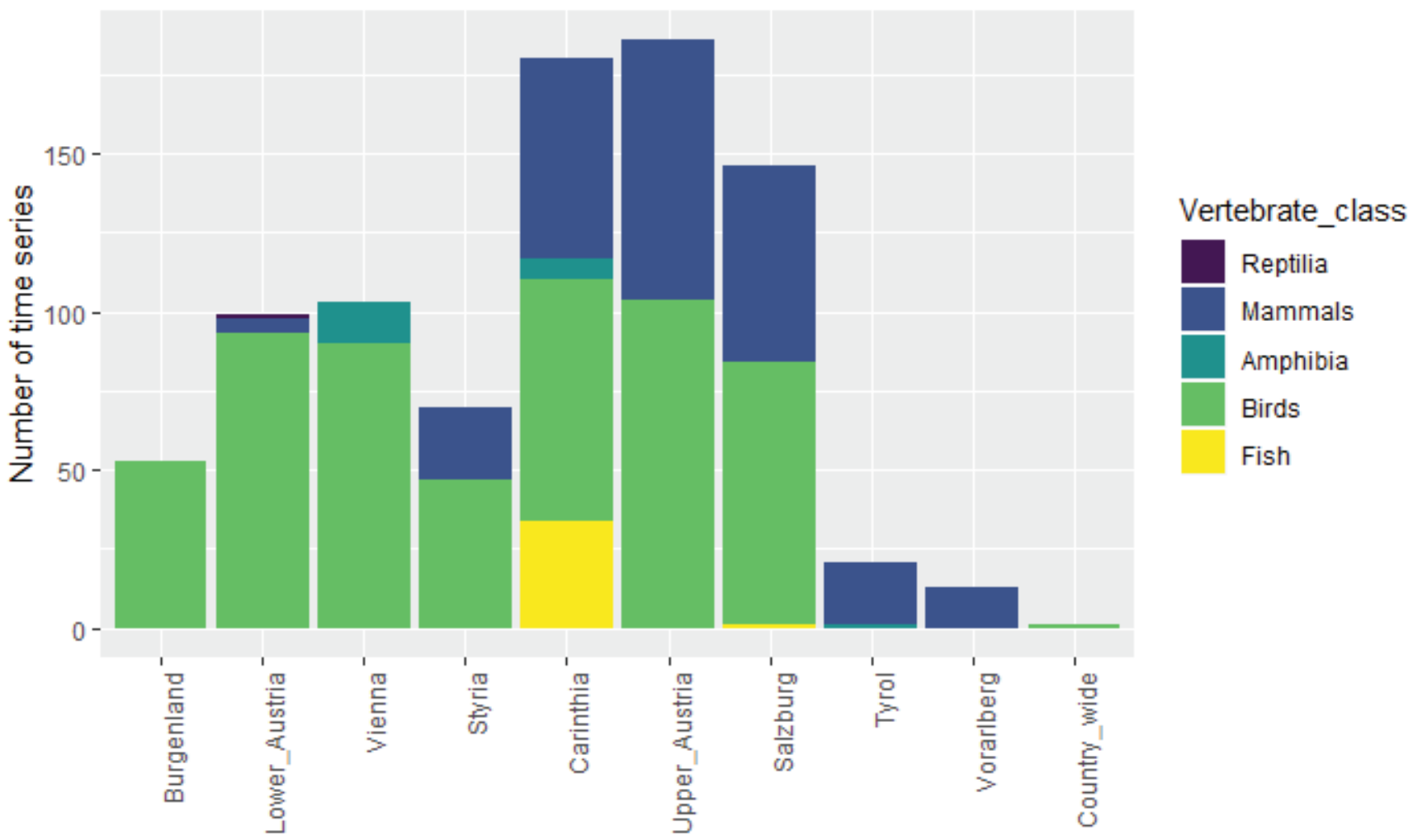

Province

Figure 2. Number of time series for the calculation of the Austrian Living Planet Index per region and animal class.

Abbildung 2. Anzahl der für die Berechnung des österreichischen Gesamt-LPI zur Verfügung stehenden Datenreihen nach Bundesland und Tierklasse.

from the base year until the mid-1990s, followed by a small increase, resulting in fluctuations around $\sim 0.6$ from 2006 until 2015 (Figure 6, right).

\section{Discussion}

\subsection{Limitations}

The present study was limited by the data available, as sufficient data are crucial for the calculation of valid indices (Collen et al., 2008). This resulted, for example, in the change of base year from 1970, which is used globally, to
1990, as there were not enough data for the index calculation before 1990. This choice of base year was a compromise between the aim to start as early as possible and the possibilities given by the length of time series available. Nevertheless, it must be seen critically that different vertebrate species are not represented well in the data set and especially in the base year. This namely applies for fishes and reptiles.

Thus, financial and personal resources for the systematic long-term monitoring of animal populations are needed (Balmford et al., 2003; McRae et al., 2017). In the longterm, it is especially important to collect data on groups such as amphibians and reptiles, which are underrepresented in research in Austria and on a global scale (McRae

Table 1. Example of data format used to calculate the LPI.

Tabelle 1. Beispiel für das Format der Datensätze zur Berechnung des LPI.

\begin{tabular}{ccccccccc}
\hline Time series & Location & Red List & Year 1 & Year 2 & Year 3 & Year 4 & Year 5 & Year 6 \\
\hline Series 1 & A & LC & 2.5 & & 8 & 3 & 5 \\
Series 2 & B & NT & 66 & 10 & & 18.9 & 5 \\
Series 3 & C & NT & & & 128 & 210 & 564 \\
\hline
\end{tabular}




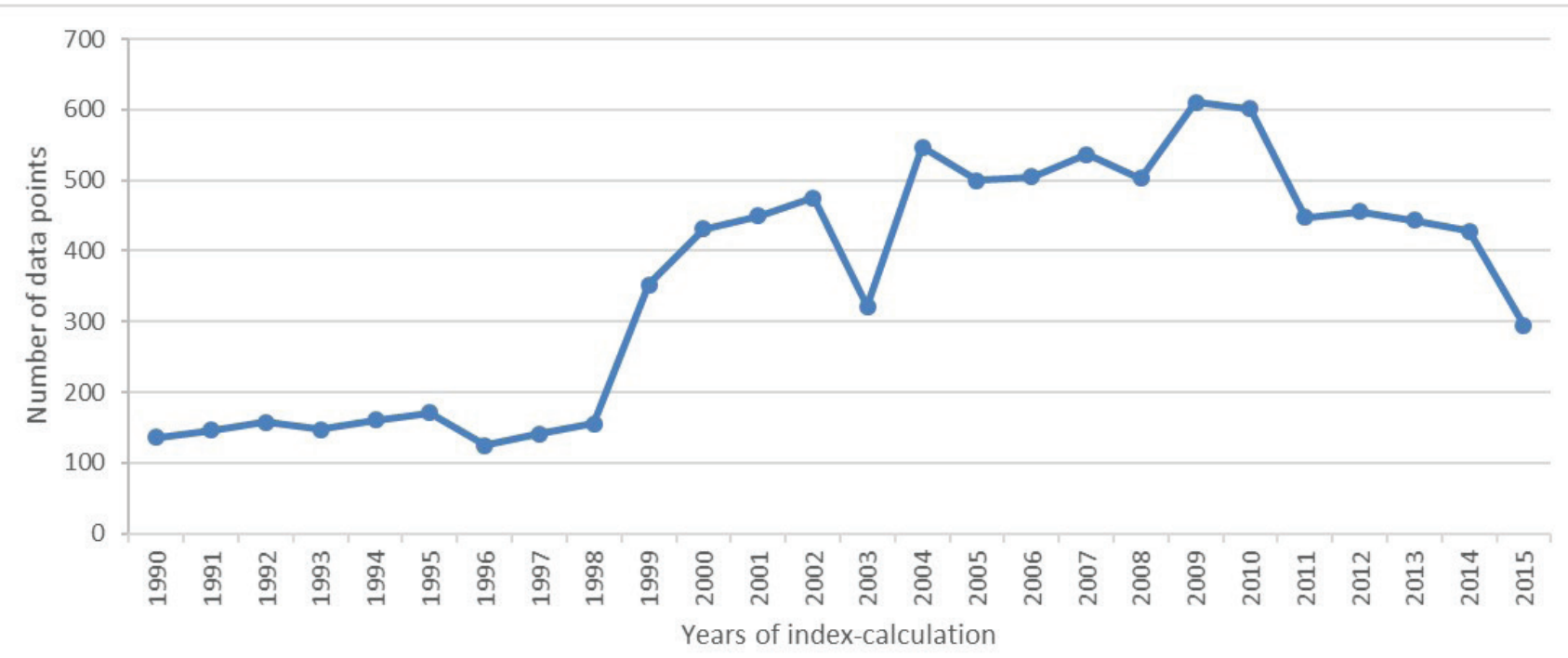

Figure 3. Number of observations per year that could be used to calculate the Austrian Living Planet Index.

Abbildung 3. Anzahl der für die Berechnung des österreichischen Gesamt-LPI zur Verfügung stehenden Beobachtungen pro Berechnungsjahr.

et al., 2008 and 2017). As a short-term solution, McRae et al. (2017) suggested the use of weighting, a method that still needs research both globally and in Austria.

The quality as well as the quantity of data is important. As much of the data collection was performed voluntarily by people who are interested in the results of the index; trust may be placed in it (McRae et al., 2008). For the Austrian LPI, the origin of all data was checked by the authors to ensure the quality of each time series. Furthermore, the focus on long time series (minimum 5 years of data) for the calculation of the Austrian LPI provides further reliability. Nevertheless, it must be seen critically that data on certain classes, namely reptiles, is so scarce.

The LPI is calculated using GAMs, so calculations include the geometric mean. Therefore, study years with population estimates of zero can be problematic. Buckland et al. (2005) suggested that $1 \%$ of the arithmetic mean over the whole time period should be added to any zeros before the calculation (Loh et al., 2005). The geometric mean underestimates high values compared to the arithmetic mean, and, therefore, the whole index may be slightly biased toward showing a trend that is too negative (Van Strien et al., 2012). Nevertheless, Van Strien et al. (2012) considered GAMs to be one of the best ways to calculate such indices, which is widely accepted and a concern in all LPIs calculated by the current method.

The LPI shows changes over time (Loh et al., 2005) in relation to a base year, rather than by considering the basic state of an ecosystem. This state is neither known nor considered in the base year (Vačkár et al., 2012), which has also been criticized (Magurran et al., 2010). The lack of knowledge of the basic state makes comparison of indices using different base years, or using the same base year, but describing ecosystems in different states, more difficult (Collen et al., 2008; Magurran et al., 2010). Nevertheless, comparisons of different regions can be made if the same base year is used (Ten Brink, 2005 and 2007). In case of the LPI, the first year of each time series is functioning as a base line for this time series (Ten Brink, 2005). This is known as the "shifting baseline syndrome" (Vačkár et al., 2012). It needs consideration in the interpretation and comparison of different LPIs.

\subsection{The Austrian LPI and its disaggregations}

The stabilization of the unweighted Austrian LPI at $\sim 0.6$ in the recent years could be seen as a fulfillment of the CBD goal to reduce biodiversity loss significantly by 2010 (Loh et al., 2005). It even suggests that the more ambitious goal of the European Union, to stop the loss of biodiversity (Pereira and Cooper, 2006), has been reached in Austria. However, this is only true if two assumptions are met: first, the diversity of vertebrate populations is representative of a broader biodiversity (Collen et al., 2008), which has not yet been assessed (Loh et al., 2005). It is, therefore, important to recognize that we can only comment on changes in vertebrate 


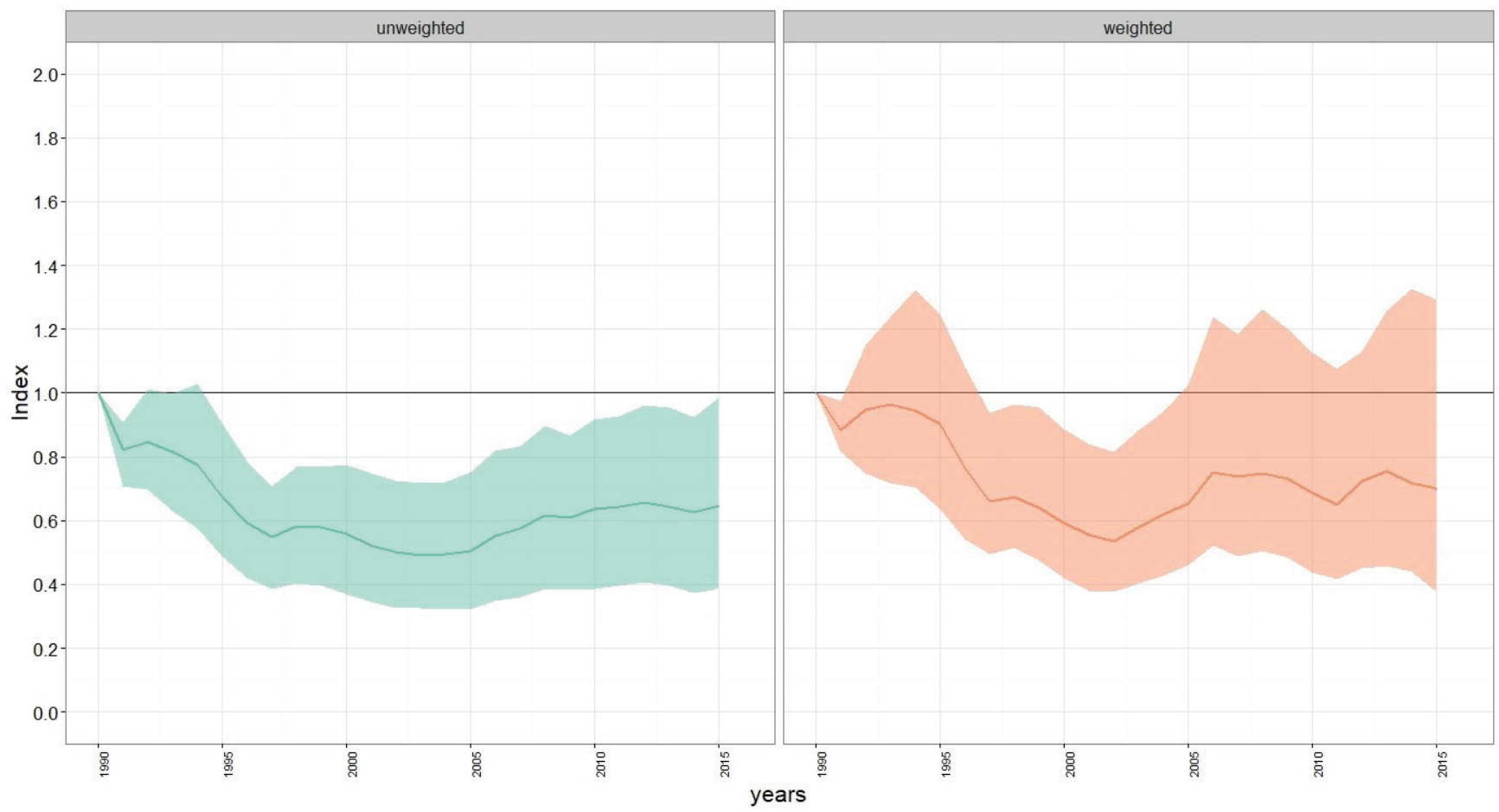

Figure 4. The unweighted (left) and weighted (right, weighting based on species richness, see Table 2) Austrian Living Planet Index. According to the data availability, the index (bold line) was calculated from the base year 1990 to 2015. The shaded areas are the $95 \%$ confidence intervals. Abbildung 4. Der LPI für Gesamt-Österreich - ungewichtet (links) und gewichtet (rechts). Das Basisjahr ist 1990. Aufgrund der Datenlage konnte der Index (durchgängige, dicke Linie) bis 2015 berechnet werden. Die schattierten Bereiche kennzeichnen die $95 \%$-Konfidenzintervalle.

populations (Collen et al., 2008). Second, the results are reliable. This has been doubted, because of the limited amount of data considered. However, even with a (hypothetical) increased amount of data, we do not know the real absolute decline in vertebrate populations because we do not know their state of decline before the first year of data collection, which forms the base year (Vackár et al., 2012).

Nevertheless, declines in population level are undoubtedly more precise and sensitive than species-level rates of decline, as the first are a warning, and measures can still be taken based on the LPIs (Collen et al., 2011). Therefore, the aim of forming a baseline for the reporting duties of Austria within international duties can be achieved partly by the use of the Austrian LPI, but it should not be the exclusive means to show trends in biodiversity.

The similarities between the LPIs for the terrestrial biome and native species result from many samples being included in both of them. The freshwater LPI consists mainly of data from fish and reflects trends in this vertebrate class, such as a peak in 2006 and a low level in 2011. However, the idea of a separate index for fish was abandoned because of unreliable results because of a small number of time series with many missing values. This shows that there is a lack of data for fish and also more broadly for the freshwater biome in Austria. More data would allow to calculate a more reliable and smoother index, because peaks of a small amount of species would not cause such big differences anymore. The similarity of the LPI for autochthonous species to the unweighted Austrian LPI confirms that the decline in vertebrate abundance occurs in native Austrian species and cannot be attributed to a decline in introduced or introduced and invasive species. Therefore, the decline in species according to the Austrian LPI does not show the successful reduction of invasive species (Essl and Rabitsch, 2004) but rather points out a severe loss of autochthonous species. However, detailed assessment of the status of invasive species might, nevertheless, show a success in their reduction and could be a goal for future analysis.

The data for mammals, fish, amphibians, and reptiles in Austria were insufficient in quantity and quality. This is similar to the global situation (McRae et al., 2017). Weighting, as was performed by McRae et al. (2017) for the global LPI, may counteract this problem if adequate coefficients can be defined for each class. It is necessary to find out potential bias in the data set (e.g., toward certain regions or groups of species; McRae et al., 2017) to implement reasonable 


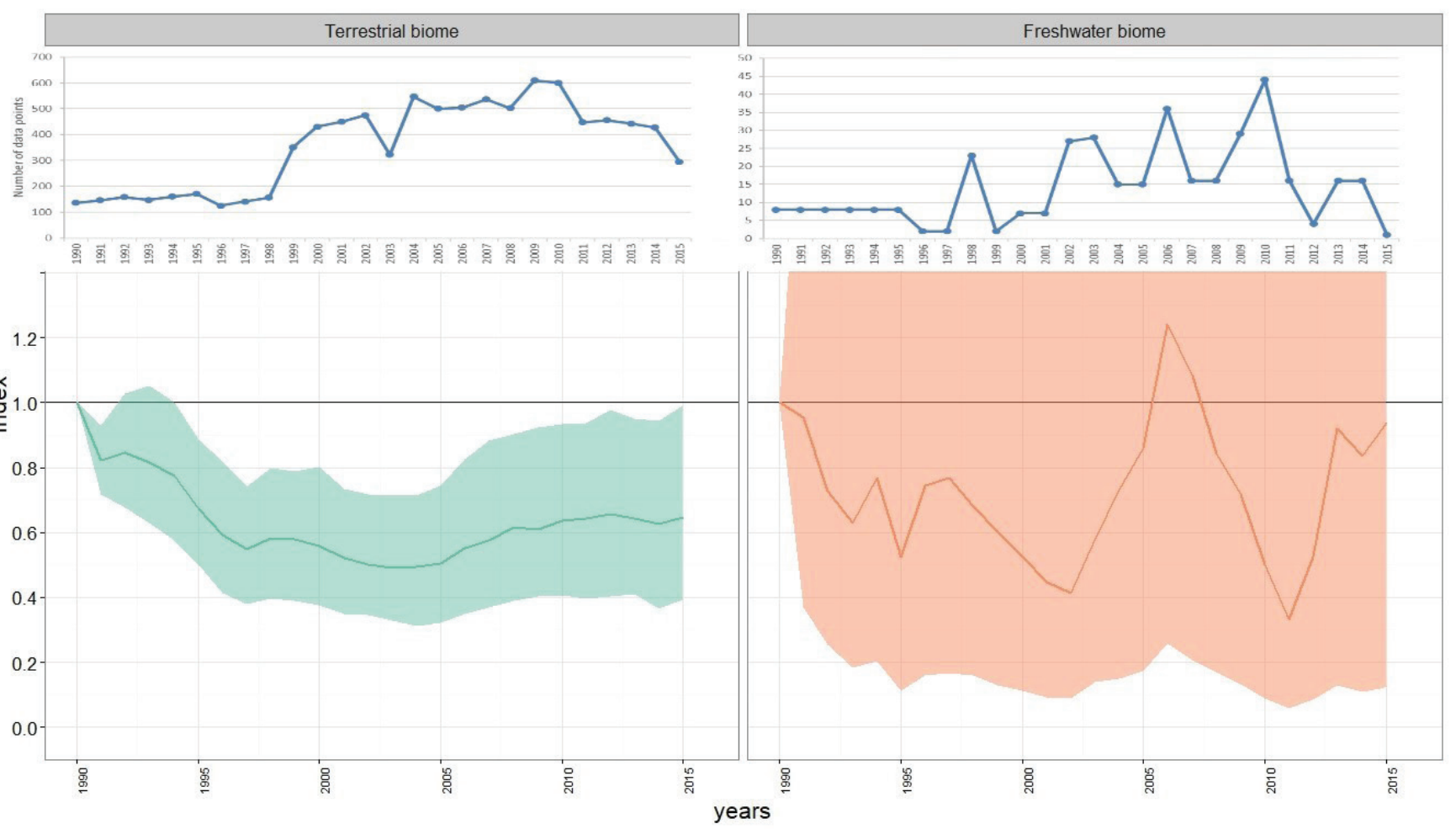

Figure 5. The unweighted Austrian Living Planet Index for the terrestrial biome (left) and the freshwater biome in Austria (right). According to the data availability, the index (bold line) was calculated from the base year 1990 to 2015. The shaded areas are the 95\% confidence intervals. Upper blue curve indicates number of observations per year that could be used to calculate the index.

Abbildung 5. Der ungewichtete LPI für das terrestrische Biom (links) und das Süßwasserbiom in Österreich (rechts), mit Basisjahr 1990. Die schattierten Bereiche kennzeichnen die 95 \%- Konfidenzintervalle. Die blaue Kurve spiegelt die Anzahl der für die Berechnung des Index zur Verfügung stehenden Beobachtungen pro Berechnungsjahr wider.

weighting. The weighting tried out on the Austrian data set is based on the number of species per class occurring in Austria (Table 2). This implicates that the highest coefficient is chosen for the class with the highest number of species, which in Austria is the class of birds. As a result, most weight is put on a class that is already overrepresented in the data set. The weighting process carried out should thus be seen as an experiment, and more research on reasonable weighting must be conducted. A better approach might be not to weigh by species but by region, because there are areas with large data deficiency in Austria. This conclusion is similar to the one drawn by McRae et al. (2017). Disaggregation by region has been carried out for the global LPI (WWF, 2016) and for some country LPIs, for example, Canada (WWFCanada, 2017), but was not possible for the Austrian LPI because of insufficient data for each of the nine provinces. This indicates the necessity of data collection, not only on a species level but also on a regional one. It, therefore, could be shown that data collection via long-term monitoring is especially needed in the western provinces, the Tyrol and
Vorarlberg, but it is necessary for certain vertebrate classes, namely, for reptiles, for fishes, and amphibians, in all provinces, but in Burgenland it is necessary also for mammals.

The short-term solution of weighting (McRae et al., 2017) may counteract data deficiency until more data are available. This may be performed by taking into account ecologi$\mathrm{cal}$, geographical, and administrational units. For example, the number of time series per Austrian province could be related to the size of the province to find out if the data set is biased toward some provinces. In addition, the amount of data from protected areas must be put in relation to the size of protected areas in the country. A comparison of the number of threatened species in Austria versus the proportion of threatened and/or protected species in the data set could also be an indication for a potential bias. We, therefore, suggest that weighting would technically work on the Austrian data set, but further research needs to be conducted to obtain reasonable results counteracting possible bias in the data set (which has not been quantified in this study). 
Table 2. Number of vertebrate species in each class occurring in Austria according to the Ministry of Sustainability and Tourism (2010) and the proportion of species richness that was used for weighting in the calculation of the Austrian LPI.

Tabelle 2. Anzahl der in Österreich vorkommenden Wirbeltierarten laut Umweltbundesamt 2010, aufgeteilt auf Tierklassen, und die daraus resultierende Gewichtung bei der Berechnung des LPI für Österreich.

\begin{tabular}{lcc}
\hline Class & Number of species occurring in Austria & Proportion used for weighting in the calculation of the LPI \\
\cline { 2 - 3 } Amphibians & 20 & 0.074 \\
Reptiles & 14 & 0.182 \\
Fish & 84 & 0.219 \\
Mammals & 101 & 0.525 \\
Birds & 242 & 1.0 \\
Total & 461 & \\
\hline
\end{tabular}

\subsection{Conservation status of birds in Austria}

Birds are the only vertebrate class that is well represented in the Austrian LPI. In Austria, changes in bird populations are also quantified by the Farmland Bird Index (Teufelbauer and Seaman, 2017) and the Woodland Bird Index (Teufelbauer et al., 2014). The Farmland Bird Index includes 22 bird species that are directly associated with agricultural land (Teufelbauer, 2015). A comparison between the Austrian Farmland Bird Index (which starts in 1998; Teufelbauer and Seaman, 2017) and the Austrian LPI for birds indicates a greater decline in farmland birds than in the broad spectrum of 205 bird species used to calculate the LPI for birds. This suggests that farmland birds are more negatively affected by habitat loss and/or human activity (Teufelbauer, 2015) than the Austrian bird fauna

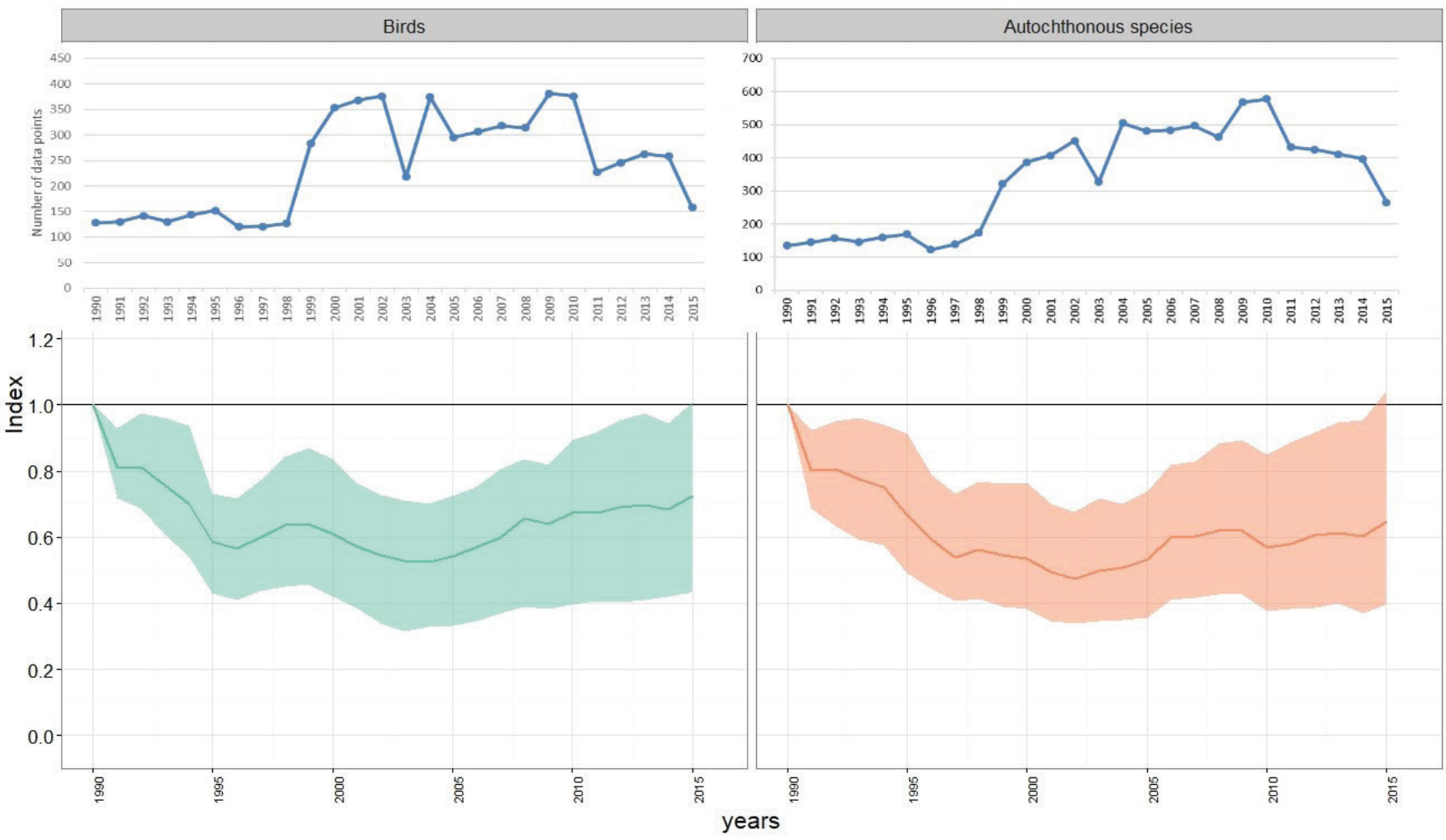

Figure 6. The unweighted Living Planet Index for birds (left) and vertebrate species native to Austria (right). According to the data availability, the index (bold line) was calculated from the base year 1990 to 2015. The dark shaded areas are the 95\% confidence intervals. Upper blue curve indicates number of observations per year that could be used to calculate the index.

Abbildung 6. Der ungewichtete Living Planet Index für Vögel (links) und autochthone Arten in Östererreich (rechts), mit Basisjahr 1990. Die schattierten Bereiche kennzeichnen die 95 \%-Konfidenzintervalle. Die blaue Kurve spiegelt die Anzahl der für die Berechnung des Index zur Verfügung stehenden Beobachtungen pro Berechnungsjahr wider. 
Table 3. Differences between the global LPI (Collen et al., 2008, WWF, 2016, Living Planet Database: http://www.livingplanetindex.org/home/ index) and the Austrian LPI.

Tabelle 3. Unterschiede zwischen globalem (Collen et al., 2008, WWF, 2016, Living Planet Database: http://www.livingplanetindex.org/home/ index) und österreichischem LPI.

\begin{tabular}{lcc}
\hline & Global LPI & Austrian LPI \\
\cline { 2 - 3 } Base year & 1970 & 1990 \\
Last year (as of January 2020) & 2014 & 2015 \\
Number of time series (as of January 2020) & More than 26,000 & 873 \\
Length of time series used to calculate LPI & Minimum 2 years & Minimum 5 years \\
Weighting & Started in 2017, regional and species level & Species level within classes \\
Biomes & Terrestrial, freshwater, marine & Terrestrial, freshwater \\
\hline
\end{tabular}

as a whole. The results of the Austrian LPI are more consistent with the Woodland Bird Index, which shows that declines in populations of 19 bird species associated with forests is much less severe than the decline in populations of farmland birds (Teufelbauer et al., 2014). The Farmland Bird Index, therefore, is designed to show human impact on birds by deliberately looking on species associated with an agricultural landscape (Teufelbauer and Seaman, 2017). On the contrary, the LPI on all data sets of Austrian birds of all kind of different habitats puts focus on the overall trends in population development without presuming a cause for such a found trend.

Although it, therefore, was possible to gain some insight in the conservation status of birds using the LPI, in combination with the research conducted using the Farmland Bird Index (Teufelbauer and Seaman, 2017) and the Woodland Bird Index (Teufelbauer et al., 2014), it was not possible to do so for other vertebrate classes, as reliable disaggregation of the LPI was not possible and habitat-specific indices for them do not exist in Austria.

\subsection{The global LPI and the Austrian LPI}

Technical differences between the global LPI and the Austrian LPI are summarized in Table 3. For the Austrian LPI, the base year, the last year of index calculation, and the minimum length of time series used to calculate the index were chosen according to the data availability. Weighting was conducted for the first time. The marine biome has not been taken into account, because Austria is a landlocked country.

Although these differences complicate the comparison, it is clear from both LPIs that the decrease in vertebrate abundance is severe (WWF, 2016). The overall decline in the global LPI is 60\% from 1970 to 2014 (WWF, 2018), and this decline is likely to continue, whereas the Austrian
LPI has stabilized at a decline of $-40 \%$ in a period between 1990 and 2015. However, if we compare the years covered by both indices and thus the decline between 1990 and 2014 , there is a decline of more than $20 \%$ in the global LPI (WWF, 2018), whereas the decline in Austria in the same period is almost $40 \%$, so almost double the global decline. It is also important to point out that any decline before 1990 is unknown for Austria. It might have been similar or even more severe than the decline on the global level. Thus, the problem of shifting base lines and unknown base states (Vačkár et al., 2012) needs to be kept in mind because it might hide severe losses from previous decades. Nevertheless, when looking at temperate terrestrial systems on a global level (Collen et al., 2008), the index does not show much change between 1970 and 2003. It stays within a range of $\sim 0.8-1.1$ and thus even shows some increase over the base level of 1, especially after 1990 (Collen, 2008; WWF, 2010). This is different for the Austrian terrestrial LPI, which declined until a level of about 0.6. Although it declined in the first years of calculation, until a level of about 0.5 , it has been slowly increasing since 2004-2005, which reflects the temperate terrestrial situation with about $10-15$ years delay. Difference in data availability and base year are two probable reasons for the differences between Austrian and the global temperate situation.

\section{Conclusion}

In conclusion, it was shown that vertebrate abundance in Austria declined $-40 \%$ between 1990 and 2014, which is almost double the decline calculated for the same period on a global level. However, more research needs to be conducted on the topic of weighting to get more precise results as a short-term solution, whereas on the long-term, more data is needed for certain classes of species and some regions. 


\section{Acknowledgments}

This study would not have been possible without data from various Austrian scientists, scientific and governmental institutes, and non-governmental organizations. We thank them for providing their knowledge and data for this project. We would also like to thank Paul Griesberger, Friedrich Leisch, and Louise McRae with her team for the statistical support. We are grateful to Nancy Jennings for checking an earlier version of this manuscript. We would also like to thank two anonymous reviewers for their valuable suggestions for improvement on previous versions of the manuscript.

\section{References}

Balmford, A., Green, R.E. and M. Jenkins (2003): Measuring the changing state of nature. Trends in Ecology \& Evolution 18, 326-330.

Butchart, S.H.M., Walpole, M., Collen, B., van Strien, A., Scharlemann, J.P.W., Almond, R.E.A., Baillie, J.E.M., Bomhard, B., Brown, C., Bruno, J., Carpenter, K.E., Carr, G.M., Chanson, J., Chenery, A.M., Csirke, J., Davidson, N.C., Dentener, F., Foster, M., Galli, A., Galloway, J.N., Genovesi, P., Gregory, R.D., Hockings, M., Kapos, V., Lamarque, J.-F., Leverington, F., Loh, J., McGeoch, M.A., McRae, L., Minasyan, A., Hernández Morcillo, M., Oldfield, T.E.E., Pauly, D., Quader, S., Revenga, C., Sauer, J.R., Skolnik, B., Spear, D., Stanwell-Smith, D., Stuart, S.N., Symes, A., Tierney, M., Tyrrell, T.D., Vié, J.-C. and R. Watson (2010): Global biodiversity: Indicators of recent declines. Science 328, 1164-1168.

Buckland, S.T., Magurran, A.E., Green, R.E. and R.M. Fewster (2005): Monitoring change in biodiversity through composite indices. Philosophical Transactions of the Royal Society B 360, 243-254.

Collen, B., Loh, J., Whitmee, S., McRae, L., Amin, R. and J.E.M. Baillie (2008): Monitoring change in vertebrate abundance: the Living Planet Index. Conservation Biology 23, 317-327.

Collen, B., McRae, L., Deinet, S., De Palma, A., Carranza, T., Cooper, N., Loh, J. and J.E.M. Baillie (2011): Predicting how populations decline to extinction. Philosophical Transactions of the Royal Society B 366, 2577-2586.

Conference of the parties (2010): COP-10 Decision X/2. Strategic Plan for Biodiversity 2011 - 2020 and the
Aichi Biodiversity Targets. In: Secretariat of the Convention on Biological Diversity, Nagoya.

Dobson, A. (2005): Monitoring global rates of biodiversity change: challenges that arise in meeting the Convention on Biological Diversity (CBD) 2010 goals. Philosophical Transactions of the Royal Society B 360, 229-241.

Essl, F. and W. Rabitsch (2004): Österreichischer Aktionsplan zu gebietsfremden Arten (Neobiota). Bundesministerium für Land- und Forstwirtschaft, Umwelt und Wasserwirtschaft, Wien.

EU European Council (2001): European Council Göteborg - Conclusions of the Presidency. Bulletin 18.06.2001, PE 305.844.

Fewster, R.M., Buckland, S.T., Siriwardena, G.M., Baillie, S.R. and J.D. Wilson (2000): Analyses of population trends for farmland birds using generalized additive models. Ecology 81, 1970-1984.

Freeman, R., McRae, L., Deinet, S., Amin, R. and B. Collen (NA): rlpi: Tools for calculating indices using the Living Planet Index method. R package version 0.1.0. https://github.com/Zoological-Society-of-London/living_planet_index.

Gepp, J. (1984): Rote Liste gefährdeter Tiere Österreichs. 2.Auflage. Bundesministerium für Gesundheit und Umweltschutz, Wien.

Habenicht, G. (2014): Bibermanagement Oberösterreich. Monitoringbericht 2014. Im Auftrag des Amts der OÖ. Landesregierung Direktion für Landesplanung, wirtschaftliche und ländliche Entwicklung, Abteilung Naturschutz.

Legg, C.J. and L. Nagy (2006): Why most conservation monitoring is, but need not be, a waste of time. Journal of Environmental Management 78, 194-199.

Loh, J., Green, R.E., Ricketts, T., Lamoreux, J., Jenkins, M., Kapos, V. and J. Randers (2005): The Living Planet Index: using species population time series to track trends in biodiversity. Philosophical Transactions of the Royal Society B 360, 289-295.

Magurran, A.E., Baillie, S.R., Buckland, S.T., Dick, J., Elston, D.A., Marian Scott, E., Smith, R.I., Somerfield, P.J., and A.D. Watt (2010): Long-term datasets in biodiversity research and monitoring: assessing change in ecological communities through time. Trends in Ecology \& Evolution 25, 574-582.

McRae, L., Deinet, S. and R. Freeman (2017): The diversity-weighted Living Planet Index: Controlling for taxonomic bias in a global biodiversity indicator. PLoS ONE 12, e0169156. 
McRae, L., Loh, J., Bubb, P.J., Baillie, J.E.M., Kapos, V. and B. Collen (2008): The Living Planet Index - guidance for national and regional use. UNEP-WCMC, Cambridge, UK.

Overmars, K.P., Schulp, C.J.E., Alkemade, R., Verburg, P.H., Temme, A.J.A.M., Omtzigt, N. and J.H.J. Schaminée (2014): Developing a methodology for a species-based and spatially explicit indicator for biodiversity on agricultural land in the EU. Ecological Indicators 37, 186-198.

Pereira, H.M. and H.D. Cooper (2006): Towards the global monitoring of biodiversity change. Trends in Ecology \& Evolution 21, 123-129.

R Core Team (2016): R: A language and environment for statistical computing. R Foundation for Statistical Computing, Vienna, Austria. https://www.R-project.org/.

Secretariat of the Convention on Biological Diversity (2005): Handbook of the Convention on Biological Diversity including its Cartagena Protocol on Biosafety, 3rd edition, Montreal, Canada.

Sittenthaler, M., Haring, E. and R. Parz-Gollner (2016): Erhebung des Fischotterbestandes in ausgewählten Fließgewässern Niederösterreichs mittels nicht-invasiver genetischer Methoden. Endbericht. Institut für Wildbiologie und Jagdwirtschaft, Universität für Bodenkultur Wien.

Ten Brink, B. (2005): A long-term biodiversity, ecosystem and awareness research network. indicators as communication tools: an evaluation towards composite indicators. Project no. GOCE-CT-2003-505298 ALTERNet. WPR2-2006-D3b.

Ten Brink, B. (2007): Contribution to Beyond GDP "Virtual Indicator Expo". Beyond GDP - International Conference 2007, Brussels.

Ter Braak, C.J.F., Van Strien, A.J., Meijer, R. and T.J. Verstrael (1994): Analysis of monitoring data with many missing values: which method? In: E.J.M. Hagemeijer and T.J. Verstrael (Eds.): Bird Numbers 1992. Distribution, monitoring and ecological aspects. Proceedings of the $12^{\text {th }}$ International Conference of IBCC and EOAC, Noordwijkerhout, The Netherlands. Statistics
Netherlands, Voorburg/Heerlen \& SOVON, BeekUbbergen, pp. 663-673.

Teufelbauer, N. (2015): Farmland Bird Index: Aktuelle Entwicklung und der Konnex zu Landschaftselementen. Online-Fachzeitschrift des Bundesministeriums für Land- und Forstwirtschaft, Umwelt und Wasserwirtschaft. Ländlicher Raum - Ausgabe 03.

Teufelbauer, N., Büchsenmeister, R., Berger, A., Seaman, B. and B. Regner (2014): Waldvogelindikator für Österreich (Woodland Bird Index) im Auftrag des Bundesministeriums für Land- und Forstwirtschaft, Umwelt und Wasserwirtschaft, Zahl: BMLFUW-LE.1.3.7/0029II/5/2012. Bundesforschungszentrum Wald \& BirdLife Österreich, Wien.

Teufelbauer, N. and B. Seaman (2017): Farmland Bird Index 2016 - 2. Teilbericht des Projekts Farmland Bird Index für Österreich: Indikatorermittlung 2015 bis 2020. BirdLife Österreich im Auftrag des Bundesministeriums für Land- und Forstwirtschaft, Umwelt und Wasserwirtschaft. Wien.

Vačkáŕ, D., ten Brink, B., Loh, J., Baillie, J.E.M. and B. Reyers (2012): Review of multispecies indices for monitoring human impacts on biodiversity. Ecological Indicators $17,58-67$.

Van der Sluis, T., Pedroli, B., Kristensen, S.B.P., Lavinia Cosorc, G. and E. Pavlis (2015): Changing land use intensity in Europe - Recent processes in selected case studies. Land Use Policy 57, 777-785.

Van Strien, A.J., Soldaat, L.L. and R.D. Gregory (2012): Desirable mathematical properties of indicators for biodiversity change. Ecological Indicators 14, 202-208.

WWF-Canada (2017): Living Planet Report Canada Technical Document. WWF-Canada, Toronto, Ontario.

WWF (2010): Living Planet Report 2010. Biodiversity, biocapacity and development. WWF International, Gland, Switzerland.

WWF (2016): Living Planet Report 2016. Risk and resilience in a new era. WWF International, Gland, Switzerland.

WWF (2018): Living Planet Report 2018. Aiming Higher. WWF, Gland, Switzerland. 